\title{
A Review on Analytical Methods for Antiviral Phytoconstituents
}

\author{
Sivagami B*, Sailaja B \\ Institute of Pharmaceutical Technology, Sri Padmavati Mahila Visvavidyalayam, Tirupati, Chitoor, District, Andhra Pradesh, INDIA.
}

\begin{abstract}
Viral infections are spreading to a great extent worldwide and affecting many people. The existing and emerging viral infections are a threat to human beings. Combating against these viral infections is a challenge with the available few antiviral drugs. Though new Antiviral drugs are being approved by the FDA every year, controlling emerging viral infections is a global concern. The currently available drugs and vaccines for the treatment of existing viral infections have limitations. From ancient times, herbs played a significant role in treating viral disorders by developing immunity towards viral infections. Some more herbs with their antipyretic and analgesic activity helped in treating fever and body aches resulted of viral infections. Antiviral phytoconstituents like alkaloids, glycosides, flavonoids, terpenoids, polyphenols, coumarins and saponins of plants have been isolated from plants and studied for their antiviral effects by researchers. Some of the phytochemicals are even developed as formulations and marketed to treat viral infections. Quality control of phytochemicals
\end{abstract}

and herbal formulations is necessary for assuring therapeutic efficacy, quality and safety of these preparations. Hence, various standardization methods are developed for ensuring the quality of herbal products. The current review encompasses the RP- HPLC, LC-MS, GC-MS and HPTLC methods available for the Single and concurrent estimation of different antiviral phytoconstituents.

Key words: Analytical methods, Antiviral Activity, Phytoconstituents.

Correspondence

Mrs. B Sivagami

Associate Professor, Department of Pharmaceutical Analysis, Seven Hills College for Pharmacy, Tirupati-517561, Chittoor, Andhra Pradesh, INDIA.

Phone: +91-09705867855

Email: sivagamib_27@rediffmail.com

DOI: 10.5530/jyp.2021.13.2

\section{INTRODUCTION}

Most of the traditional systems of medicine are effective against many diseases, but standardization needs to be improved in certain stages of production. A number of new herbal products are introduced in the global market every year. $80 \%$ of the people in many parts of the world still rely on traditional herbal medicine and their products for their primary health care and living. ${ }^{1}$ Many medicinal plant species have been recorded globally ${ }^{2,3}$ In the present scenario more than $25 \%$ of the drugs are obtained from plant derived compounds. ${ }^{4}$ Quality control methods need to be improved at every stage of production to ensure the quality, safety and efficacy. Hence, better standardization methods are needed to ensure the quality of products. Standardized herbal products of reliable quality and well defined phytoconstituents are required for clinical trials and to produce beneficial therapeutic efficacy.

The combination of high performance liquid chromatography and mass spectrometry (LC/MS) has a considerable impact on drug discovery and development of natural products. With the development of more sophisticated instrumentation and efficient column materials the HPLC and LC-MS techniques have now become more precise and reliable. Sometimes, the data generated from a single method is not enough to solve the problems of the confirmation of the structures of some molecules. The traditional method of extraction and isolation of these compounds using different chromatographic and spectroscopic methods such as TLC, column chromatography, flash chromatography, GC, HPLC, HPTLC, FTIR, NMR and MS have been progressively investigated to obtain and facilitate the identification of the bioactive compounds. ${ }^{5}$

The study design involves the development of new reverse phase HPLC and LC-MS methods for estimation of natural products, validation of the methods thus developed and testing their suitability for estimation of natural products. Chromatographic methods are very useful for the analysis of various classes of phytochemicals including alkaloids, coumarins, phenolic acids, flavonoids and isoflavonoids, terpenes and steroids. Phytocompounds play a crucial role in the field of drug discovery and development of antiviral agents with significant pharmacological effects. ${ }^{6,7}$ Many anti-infective and anticancer drugs are derived from plant derived compound $s^{8}$ Herbal practitioners used herbal medicine since ancient times to cure several human aliments. ${ }^{9}$ To treat innumerable inflictions and diseases.

Literature review on the analytical methods of some natural compounds by HPLC and LC-MS/MS, GC-MS and HPTLC methods are available for the estimation of natural products. The proposed methods can be less tedious and economical. The proposed methods can be used as alternative methods to those reported by the earlier workers and provide good choice for the routine determination of natural products. The current review encompasses the different method development and validation for the concurrent estimation of phytoconstituents. Since proper standardization methods are not available for herbal formulations this review gives an overview of Phytochemical compounds developed and validated by HPLC, LC-MS, HPTLC and GC-MS methods. Figure 1 represents the phytoconstituents and analytical methods.

\section{Extraction and Isolation of Phytoconstituents}

Many factors such as different solvents used for the extraction of bioactive molecules, choice of plant part and choice of solvents for extraction of bioactive compounds often play vital roles in extracting the biologically active phytoconstituents from plants effectively. To evaluate the antiviral activity of plants efficient approach for the extraction, isolation and characterization of bioactive molecules and virus replication inhibition assays in animals are definitely required before such phytoconstituents 
could actually be employed to treat viral diseases..$^{10}$ Different methods for isolation, purification of bioactive compounds from the extracts of plant to carry out biological activity such as their antiviral, antibacterial, antifungal properties etc, are required to be established. Extraction of phytopharmaceuticals is a significant step in the analysis of plants to extract the desired Phytochemicals. ${ }^{11,12}$

Collecting information from local or ethnic group of people on usage of traditional and complementary alternative medicine using ethno medicinally important plants to extract bioactive compounds for curing various diseases or disorders are quite challenging. The pharmacological activity of herbal products depends on phytoconstituents present in them. Novel analytical methods can be developed and validated which can invariably outline the phytochemical compounds, including quantitative analyses of natural compounds and other major constituents, is a major challenge to scientists and researchers. Consistent therapeutic efficacy is not predictable without reliable quality of a phytochemical mixture. Chromatographic methods are relatively more useful techniques for qualitative and quantitative determination of drugs. ${ }^{13,14}$ Different analytical methods for antiviral phytoconstituents are depicted in Table 1.

Medicinal plants play a valuable role in the field of research and development in exploring, extracting and establishing medicinal properties. Only very few phytoconstituents has been clinically evaluated for their therapeutic potential. Secondary metabolites which have been observed to combat viral infections include alkaloids, coumarins, flavonoids, lignins, polyphenols, proanthocyanidins, polysaccharides, saponins, quinones, terpenes, tannins, steroids and thiosulfonates are prominent bioactive phytochemicals. Medicinal Plants have natural tendency to treat various infections, diseases and disorders which have been nature's gift with rich source of phytoconstituents with wide therapeutic efficacy. Very few of the phytoconstituents have been standardized, purified and studied for their structural activity relationship and pharmacological effects. Most of the medicinal plant products have been marketed as herbal products without certified standardization, quality and efficacy. Many traditional medicinal plants and herbs have been reported to have strong antiviral activity against many viral infections. These

Table 1: Analytical methods for the Antiviral Phytoconstituents.

\begin{tabular}{|c|c|c|c|c|}
\hline Biological Source & Phytoconstituents & Column used & Mobile phase & Analytical method \\
\hline Zingiber officinalis & $\begin{array}{c}\text { [6]-, [8]- and [10]-gingerol, } \\
\text { [6]-, [8]- and [10]-shogaol, } \\
\text { [6]-paradol and } \\
\text { [1]-dehydrogingerdione }\end{array}$ & $\begin{array}{l}150 \mathrm{~mm} \times 4.6 \mathrm{~mm}, 5 \mu \mathrm{m} \\
\text { Supelcosil }^{\mathrm{Ts}} \mathrm{LC}_{18} \text { column }\end{array}$ & $\begin{array}{l}\text { The mobile phases consisted of solvent } \\
\text { A ( } 30 \mathrm{mM} \text { sodium phosphate buffer, } \\
\text { pH } 3.35 \text { ) Solvent B ( } 15 \mathrm{mM} \text { sodium } \\
\text { phosphate buffer containing } 58.5 \% \\
\text { acetonitrile and } 12.5 \% \text { tetrahydrofuran, } \\
\text { pH } 3.45 \text { ). }\end{array}$ & HPLC $^{16}$ \\
\hline${ }^{\mathrm{OCH}_{3}}$ Shogoal & & & & \\
\hline Zingiber zerumbet $\mathrm{L}$. & $\begin{array}{l}\text { Sesquiterpenes (Zerumbone and } \\
\text { a-humulene) }\end{array}$ & $\begin{array}{l}\text { polydimethylsiloxane } \\
\quad(\text { PDMS, } 7 \mu \mathrm{m}), \\
\text { polyacrylate }(\mathrm{PA}, 85 \mu \mathrm{m})\end{array}$ & $70^{\circ} \mathrm{C}$ and $30 \mathrm{~min}$ & $\begin{array}{l}\text { (HS-SPME) } \\
\text { coupled with gas } \\
\text { chromatography }(\text { GC- } \\
\text { FID) HS-SPME-GC }{ }^{17}\end{array}$ \\
\hline Zingiber officinale & $\begin{array}{c}\text { 6-gingerol, 6-shogaol, 8-gingerol, } \\
\text { 8-shogaol, 10-gingerol, } \\
\text { 10-shogaol, Zingerone and } \\
\text { 6-isodehydrogingenone }\end{array}$ & $\begin{array}{l}\text { Syncronis } \mathrm{C}_{18} \text { column }(100 \\
\quad \times 2.1 \mathrm{~mm}, 1.7 \mu \mathrm{m})\end{array}$ & $\begin{array}{c}\text { The mobile phase consisted of } \\
\text { acetonitrile and } 0.1 \% \text { formic acid in } \\
\text { water }\end{array}$ & $\begin{array}{c}\text { (UPLC-Q-Extractive- } \\
\text { HRMS) }{ }^{18}\end{array}$ \\
\hline Syzygium aromaticum & Eugenol & cosmosil $\mathrm{C}_{18}$ column, & methanol: distilled water $(60: 40, \mathrm{v} / \mathrm{v})$ & RPHPLC $^{19}$ \\
\hline Solanum anguivi & Solasodine & $\mathrm{C}_{18}$ column & $\begin{array}{c}\text { methanol: } \mathrm{KH} 2 \mathrm{PO} 4 \text { buffer }(\mathrm{pH} 2.5) \text { at } \\
\text { the ratio of } 75: 25 \% \mathrm{v} / \mathrm{v}\end{array}$ & RP-HPLC ${ }^{20}$ \\
\hline $\begin{array}{l}\text { Vidang Embelia ribes } \\
\text { Mallotus philippensis, } \\
\text { Terminalia chebula }\end{array}$ & $\begin{array}{l}\text { Embelin, Rottlerin and Ellagic } \\
\text { acid }\end{array}$ & $\begin{array}{l}\text { reversed phase } \mathrm{C}_{18} \text { column } \\
\text { eluted with gradient } \\
\text { mobile phase of }\end{array}$ & $\begin{array}{l}\text { The mobile phases consisted of } \\
\text { acetonitrile and water }\end{array}$ & RP-HPLC ${ }^{21}$ \\
\hline
\end{tabular}




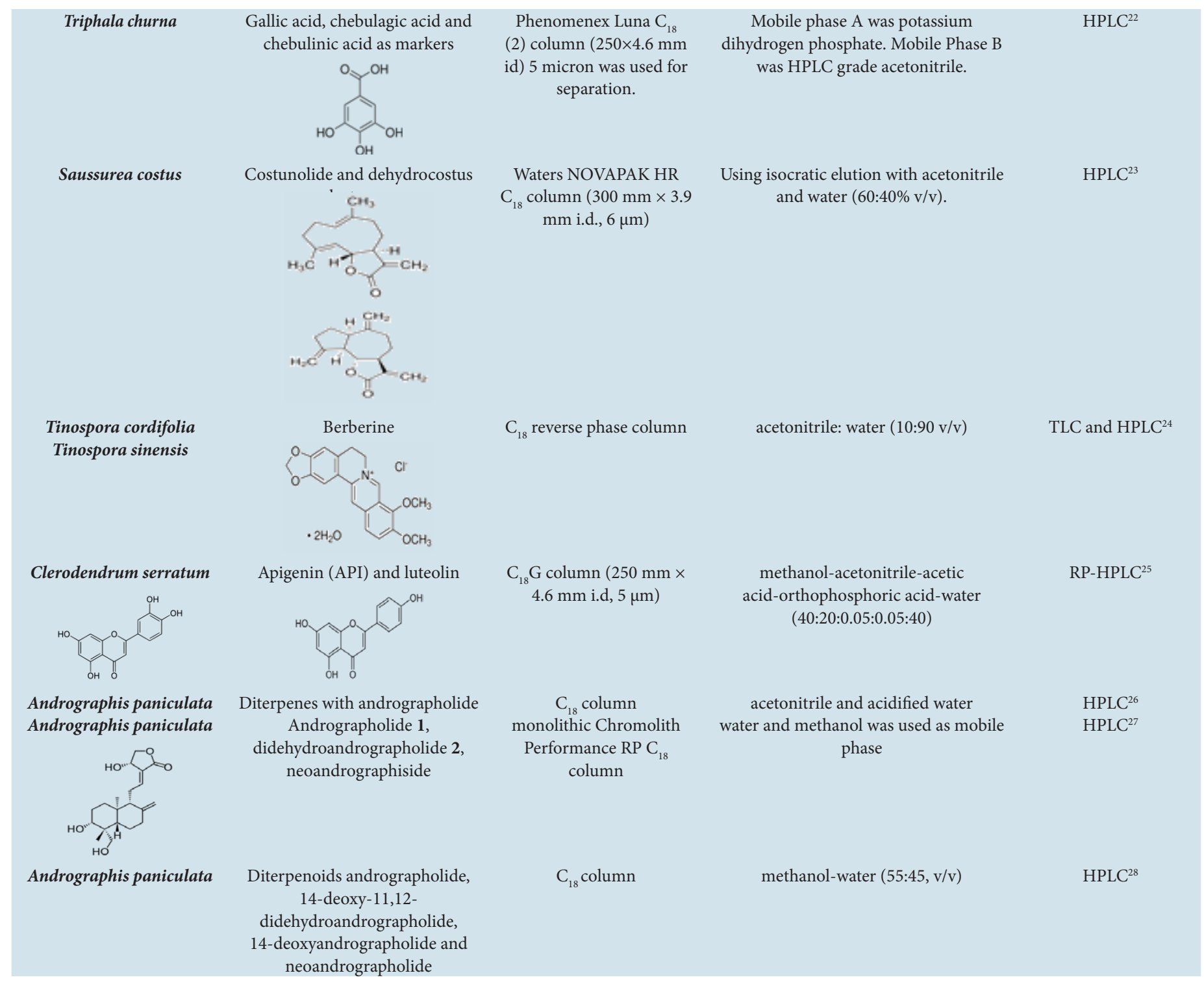

Table 2: HPTLC methods for the Antiviral Phytoconstituents.

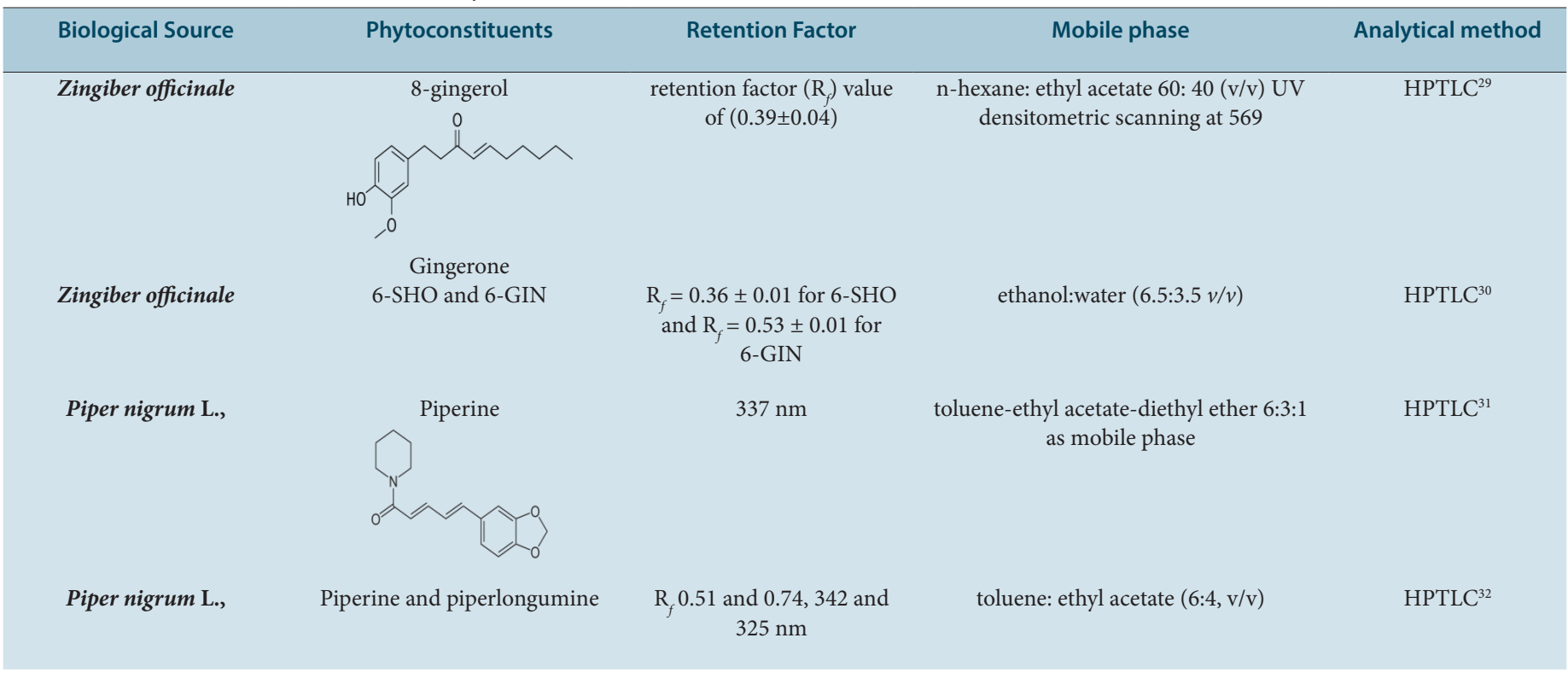




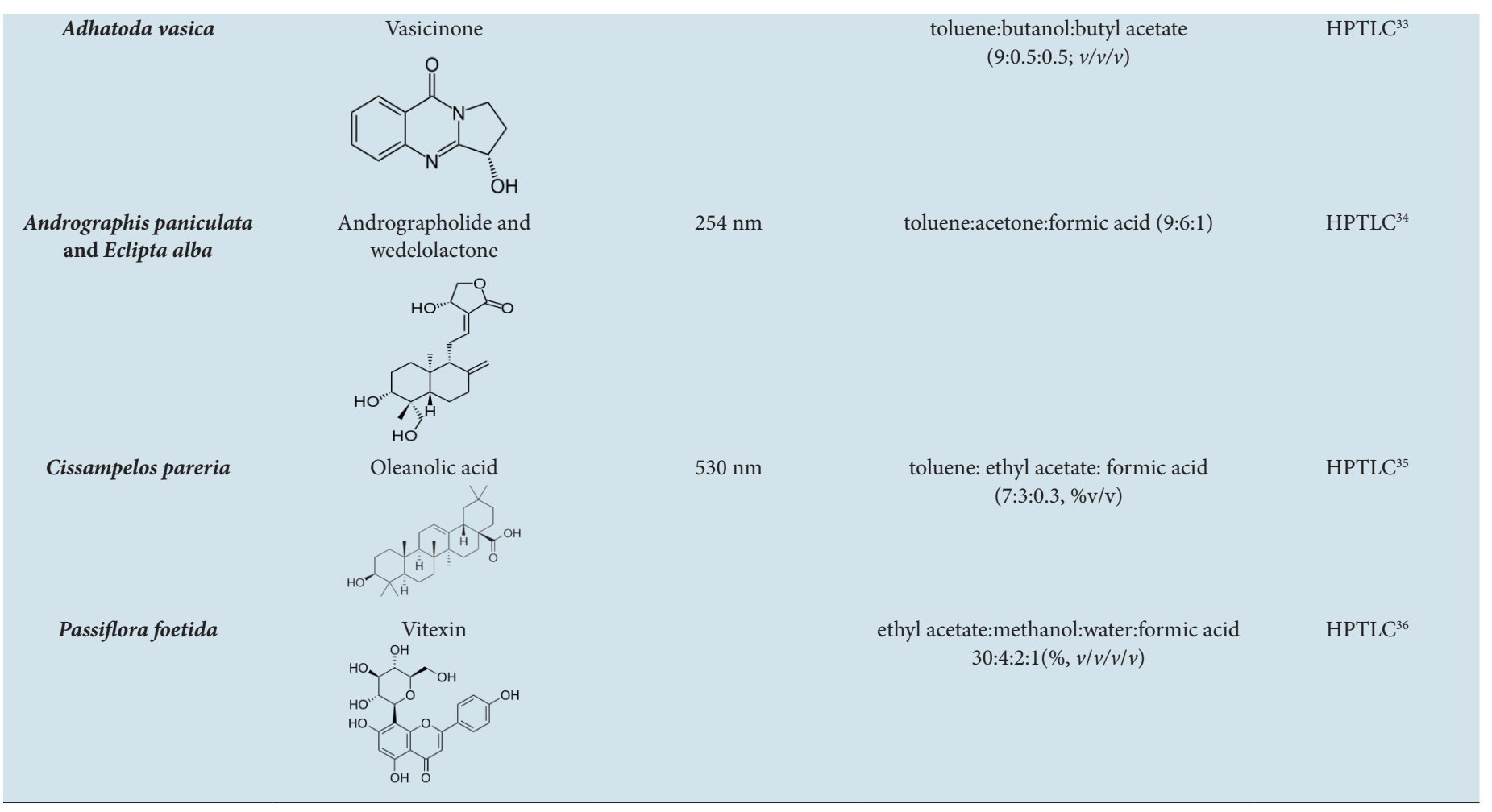

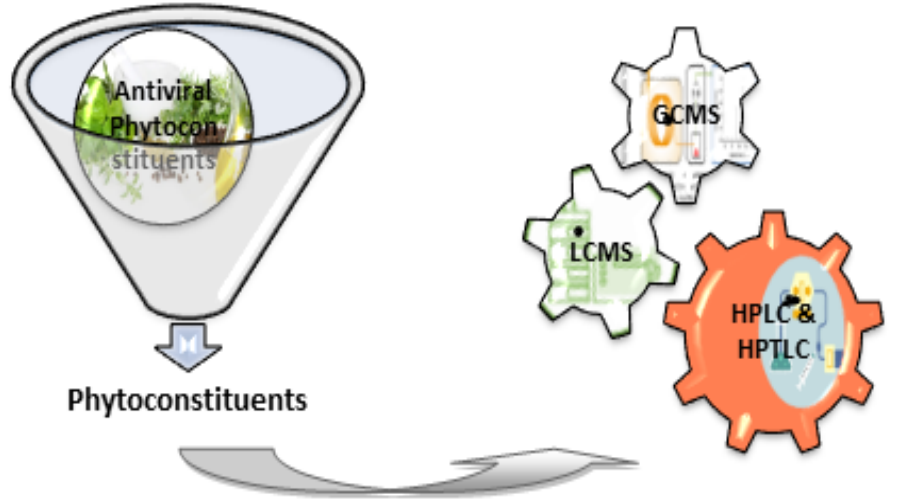

Figure 1: Phytoconstituents and Analytical Methods..$^{56-58}$

phytoconstituents must be subjected to preclinical studies and human clinical trials to determine their effectiveness in whole-organism systems and toxicity studies. ${ }^{15}$ HPTLC methods for the Antiviral Phytoconstituents are given in Table 2.

\section{Antiviral Phytoconstituents of Pharmaceutical Importance}

\section{Antiviral activity of Flavonoids}

Flavonoids are natural products belonging to plant secondary metabolites they are compounds having a polyphenolic structure present in fruits, vegetables and medicinal plants. They have antioxidant free radical scavenging activity associated with various diseases such as viral infections, cardiovascular diseases, anti-cancer, neurological disorders, skin diseases and various other acute and chronic diseases. Flavonoids are class of bioactive compounds having potent anti-viral, antioxidant and anti-carcinogenic potential. Flavonoids can be extracted and isolated from fruits, colored pigments, vegetables and medicinal plants.
They are potent active constituents present in fruits and vegetables flavonoids are a group of phenolic compounds which are categorized into flavonols, flavones, catechins, flavonones, anthocyanidins, isoflavonoids, coumarins and chalcones etc. Recent studies are proven to be done to enhance the efficacy and bioavailability of flavonoids. Flavonoids are proven to be most effective against many diseases. These flavonoids are compounds which have immunomodulatory activity which can boost our immune system and prevent the body against many diseases like viral, cardiovascular, cancer, neuroprotective and so on.

\section{Antiviral activity of Alkaloids}

Alkaloids are secondary metabolites of plants origin consisting of nitrogen atom in the heterocyclic ring. Alkaloids are generally present in plants and comprise of various biological activities like antiviral, anti-inflammatory, anticancer, antibacterial, etc. Alkaloids have been observed to exhibit better therapeutic activity against various viral infections. The antiviral activity against virus by the alkaloids can be due to the immunomodulatory activity of phytoconstituents. ${ }^{37}$

\section{Antiviral activity of Terpenoids}

Terpenes consist of five carbon $\left(\mathrm{C}_{5} \mathrm{H}_{8}\right)$ compounds, isoprene units with hydrocarbons, obtained from isoprenoid biosynthesis and belong to the largest class of secondary metabolites. Terpenoids are class of compounds present in natural products with various pharmacological activities. Terpenoids are obtained from isoprenoid compounds present in plants and have a significant role in treating viral infections, as phytopharmaceuticals with better therapeutic activity. ${ }^{37}$ Table 3 specifies Antiviral Phytoconstituents of Pharmaceutical Importance.

\section{CONCLUSION AND FUTURE PERSPECTIVES}

Antiviral phytoconstituents play a critical role in curing and treating viral infections. Available antiviral medicines from ancient system of medicine such as Ayurveda, Siddha, Unani and Homeopathy are being used as alternative medicines against viral infections. 
Table 3: Antiviral Phytoconstituents of Pharmaceutical Importance.

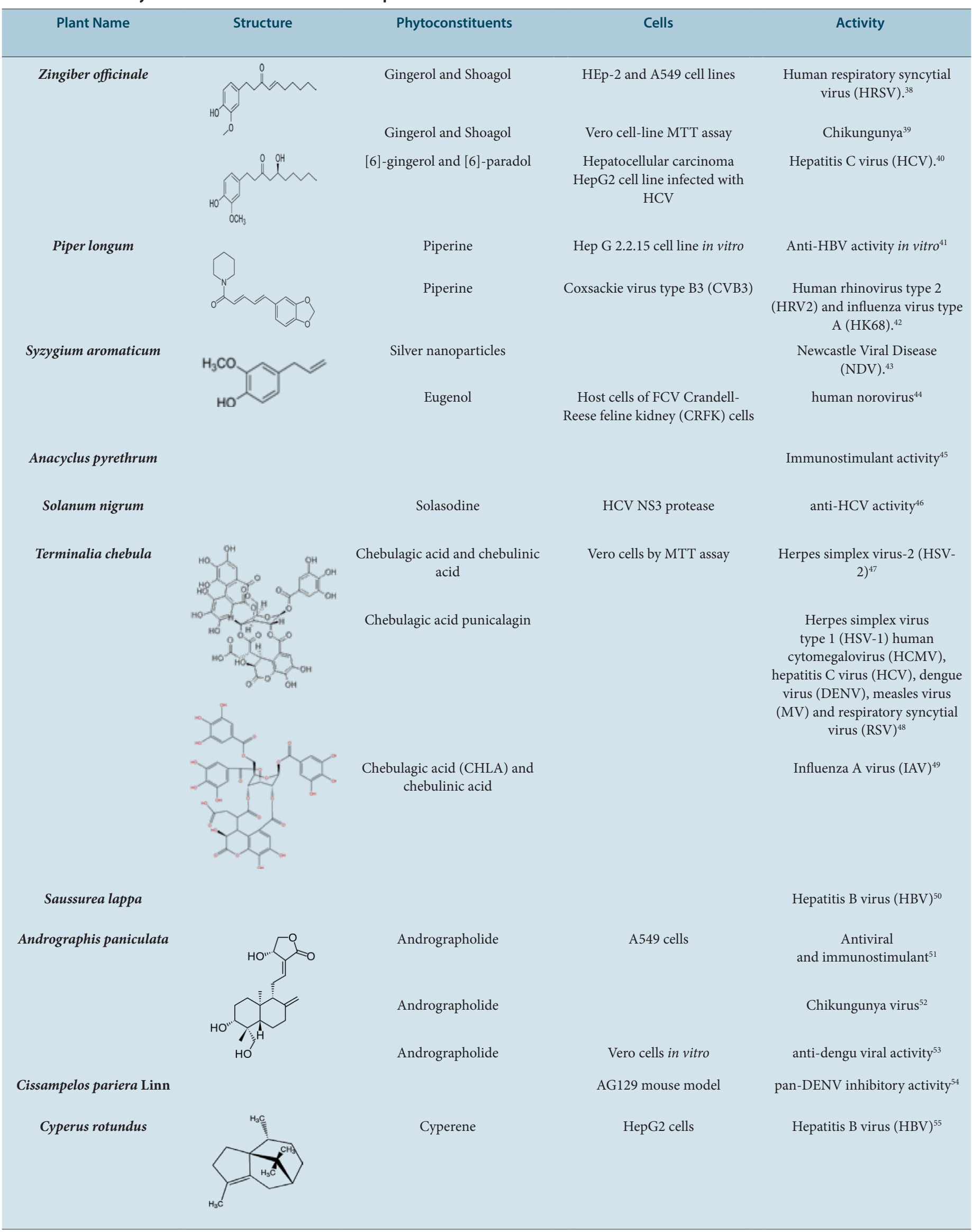


Several standardized protocols are available on authentication of herbs, isolation, characterization and estimation of active antiviral phytochemicals. Generally, in herbs active phytoconstituents exist along with other complex mixtures of compounds. Highly sensitive and selective spectroscopic and chromatographic methods are widely in use for identification and characterization of antiviral phytochemicals to overcome the interference of other constituents present in herbal formulations. Analytical methods such as RP-HPLC, HPTLC and hyphenated analytical methods like HPLC-MS/NMR, LC-MS and LC-NMR have been established as significant selective tools in the estimation of antiviral phytochemicals. Standardization and quality control of antiviral phytochemicals could be improved by using these sensitive analytical methods.

\section{CONFLICT OF INTEREST}

The authors declare no conflict of interest.

\section{ABBREVIATIONS}

TLC: Thin layer chromatography; NMR: Nuclear Magnetic Resonance; LC-MS/MS: Liquid chromatography mass spectroscopy; HPLC: High performance liquid chromatography; HPTLC: High performance thin layer chromatography; UFLC: Ultrafast liquid chromatography; FDA: Food and drug administration; GC-MS: Gas chromatography mass spectroscopy; IR: Infrared Spectroscopy; HS-SPME: Headspace-solid phase microextraction.

\section{REFERENCES}

1. Farnsworth NR, Akerele O, Bingel AS, Soejarto DD, Guo Z. Medicinal plants in therapy. Bull World Health Organ. 1985;63(6):965-81.

2. Guasch L, Sala E, Ojeda MJ, Valls C, Bladé C, Mulero M, et al. Identification of novel human dipeptidyl peptidase-IV inhibitors of natural origin (Part II): In silico prediction in antidiabetic extracts. PLoS One. 2012;7(9):e44972.

3. Slikkerveer LJ. (2006). The challenge of non-experimental validation of mac plants: Towards a multivariate model of transcultural utilization of medicinal, aromatic and cosmetic plants.

4. Hostettmann K, Marston A. Twenty years of research into medicinal plants: Results and perspectives. Phytochem Rev. 2002;1:275-85.

5. Pitt JJ. Principles and applications of liquid chromatography-mass spectrometry in clinical biochemistry. Clin Biochem Rev. 2009;30(1):19-34.

6. Hostettmann KM, Marston A, Ndjoko K, Wolfender JL. The potential of African plants as a source of drugs. Curr Org Chem. 2000;4:973-1010.

7. Cos P, Maes L, Vanden BD, Hermans N, Pieters L, et al. Plant substances as anti-HIV agents selected according to their putative mechanism of action. J Nat Prod. 2004;67(2):284-93

8. Sala E, Guasch L, Iwaszkiewicz J, Mulero M, Salvado MJ, et al. Identification of human IKK-2 inhibitors of natural origin (Part II): In silico prediction of IKK-2 inhibitors in natural extracts with known anti-inflammatory activity. Eur $\mathrm{J}$ Med Chem. 2011;46(12):6098-103.

9. Cragg GA, Newman DJ. Biodiversity: A continuing source of novel drug leads. Pure Appl Chem. 2005;77(1):7-24.

10. Esposito F, Carli I, Vecchio CD, Xu L, Corona A, et al. Sennoside A, derived from the traditional Chinese medicine plant Rheum L., is a new dual HIV-1 inhibitor effective on HIV-1 replication. Phytomed. 2016;23(12):1383-91.

11. Altemimi A, Lakhssassi N, Baharlouei A, Watson DG, Lightfoot DA. Phytochemicals: Extraction, Isolation and Identification of Bioactive Compounds from Plant Extracts. Plants. 2017:6(4):42.

12. Yuan H, Ma Q, Ye L, Piao G. The Traditional Medicine and Modern Medicine from Natural Products. Molecules. 2016;21(5):559.

13. Atanasov AG, Waltenberger B, Pferschy-Wenzig EM, et al. Discovery and resupply of pharmacologically active plant-derived natural products: A review. Biotechnol Adv. 2015;33(8):1582-614.

14. Ko KM. New Perspectives on How to Discover Drugs from Herbal Medicines: CAM's Outstanding Contribution to Modern Therapeutics. Evid Based Complement Alternat Med. 2013;627375.

15. Anand U, Jacobo-Herrera N, Altemimi A, Lakhssassi N. A Comprehensive Review on Medicinal Plants as Antimicrobial Therapeutics: Potential Avenues of Biocompatible Drug Discovery. Metabolites.2019;9(11):258.

16. Shao X, Lv L, Parks T, Wu H, Ho CT, Sang S. Quantitative analysis of ginger components in commercial products using liquid chromatography with electrochemical array detection. J Agric Food Chem. 2010;58(24):12608-14.
17. Bhavya ML, Ravi R, Madhava NM. Development and validation of headspace Solid-Phase microextraction coupled with gas chromatography (HS-SPME-GC) method for the analysis of zingiber zerumbet L. Nat Prod Res. 2019;22:1-5.

18. Li LL, Cui Y, Guo XH, Ma K, Tian P, Feng J, et al. Pharmacokinetics and Tissue Distribution of Gingerols and Shogaols from Ginger (Zingiber officinale Rosc.) in Rats by UPLC- $\mathrm{C}-\mathrm{Exactive}^{-} \mathrm{HRMS}^{-}$. Molecules. 2019:24(3):512.

19. Saran S, Menon S, Shailajan S, Pokharna P. Validated RP-HPLC method to estimate eugenol from commercial formulations like Caturjata Churna Lavangadi Vati, Jatiphaladi Churna, Sitopaladi Churna and clove oil. Journal of Pharmacy Research. 2013;6(1):53-60.

20. Khandani SK, Mehrabani M, Sharififar F, Pardakhty A, Pournamdari M Development and Validation of an RP-HPLC Method for Determination of Solasodine, a Steroidal Alkaloid. J Young Pharm. 2019;11(1):21-5.

21. Patel RK, Patel VR, Patel MG. Development and validation of a RP-HPLC method for the simultaneous determination of Embelin, Rottlerin and Ellagic acid in Vidangadi churna. J Pharm Anal. 2012;2(5):366-71.

22. Pawar V, Lahorkar P, Anantha NDB. Development of a RP-HPLC Method for Analysis of Triphala Curna and its Applicability to Test Variations in Triphala Curna Preparations. Indian J Pharm Sci. 2009;71(4):382-6.

23. Vadaparthi RPR, Kumar K, Sarma VU, Hussain QA, Babu KS. Estimation of Costunolide and Dehydrocostus Lactone in Saussurea lappa and its Polyherbal Formulations followed by their Stability Studies using HPLC-DAD. Pharmacogn Mag. 2015;11(41):180-90.

24. Srinivasan GV, Unnikrishnan KP, Rema SAB, Balachandran I. HPLC Estimation of berberine in Tinospora cordifolia and Tinospora sinensis. Indian J Pharm Sci. 2008;70(1):96-9.

25. Rajagopal SS, Vazhayil BK, Varghese L, Nanjaian M. Development and Validation of RP-HPLC Method for Simultaneous Determination of Apigenin and Luteolin in Ethanol Extract of Clerodendrum serratum (Linn.) Leaves. AJAS. 2017:5(1). [cited 2021Jan.18] Available from: https://www.ajouronline.com/index.php/ AJAS/article/view/4393

26. Karioti A, Timoteo P, Bergonzi MC, Bilia AR. A Validated Method for the Quality Control of Andrographis paniculata Preparations. Planta Med. 2017;83(1415):1207-13

27. Villedieu-Percheron E, Ferreira V, Campos JF, Destandau E, Pichon C, BerteinaRaboin S. Quantitative Determination of Andrographolide and Related Compounds in Andrographis paniculata Extracts and Biological Evaluation of Their Anti-Inflammatory Activity. Foods. 2019;8(12):683.

28. Fu S, Du L, Yuan Y, He X. Quality Evaluation of Andrographis paniculata Capsules Based on Rapid and Accurate LC-ESI-MS/MS Assay of Three Diterpenoids. J Chromatogr Sci. 2019;57(8):708-14.

29. Alam P. Densitometric HPTLC analysis of 8-gingerol in Zingiber officinale extract and ginger-containing dietary supplements, teas and commercial creams. Asian Pac J Trop Biomed. 2013;3(8):634-8.

30. Foudah Al, Shakeel F Yusufoglu HS, Ross SA Alam P. Simultaneous Determination of 6-Shogaol and 6-Gingerol in Various Ginger (Zingiber officinale Roscoe) Extracts and Commercial Formulations Using a Green RP-HPTLCDensitometry Method. Foods. 2020;9(8):1136.

31. Rajopadhye AA, Upadhye A. Mujumdar. HPTLC Method for Analysis of Piperine in Fruits of Piper Species. Journal of Planar Chromatography - Modern TLC. 2011;24:57- 9

32. Rajopadhye AA, Namjoshi TP, Upadhye AS. Rapid validated HPTLC method for estimation of piperine and piperlongumine in root of Piper longum extract and its commercial formulation. Rev Bras Farmacogn. 2012;22(6):1355-61.

33. Panigrahi J, Gantait S, Patel IC. Concurrent production and relative quantification of vasicinone from in vivo and in vitro plant parts of Malabar nut (Adhatoda vasica Nees). 3 Biotech. 2017;7(5):280.

34. Patel MB, Kadakia VM, Mishra SH. Simultaneous estimation of andrographolide and wedelolactone in herbal formulations. Indian J Pharm Sci. 2008;70(5):68993.

35. Patel V, Shukla S, Patel K. Validated HPTLC method for qualitative and quantitative estimation of oleanolic acid in roots of Cissampelos pareira Linn. var. hirsuta, Menispermaceae. Der Pharmacia Lettre. 2015;7(5):300-6.

36. Foudah Al, Alam P, Kamal YT, Alqasoumi SI, Alqarni MH, Ross SA, et al. Development and validation of a high-performance thin-layer chromatographic method for the quantitative analysis of vitexin in Passiflora foetida herbal formulations. Saudi Pharm J. 2019;27(8):1157-63.

37. Ghildiyal R, Prakash V, Chaudhary VK, Gupta V, Gabrani R. Phytochemicals as Antiviral Agents: Recent Updates. Plant-derived Bioactives. 2020;279-95.

38. Chang JS, Wang KC, Yeh CF, Shieh DE, Chiang LC. Fresh ginger (Zingiber officinale) has anti-viral activity against human respiratory syncytial virus in human respiratory tract cell lines. J Ethnopharmacol. 2013; 145(1):146-51.

39. Kaushik S, Jangra G, Kundu V, Yadav JP, Kaushik S. Anti-viral activity of Zingiber officinale (Ginger) ingredients against the Chikungunya virus. Virusdisease. 2020;31(3):1-7.

40. Abd El-Wahab A, El-Adawi $\mathrm{H}$, El-Demellawy M. In vitro study of the antiviral activity of Zingiber officinale. Planta Med. 2009;75(09):PF7.

41. Jiang ZY, Liu WF, Zhang XM, Luo J, MaYB, Chen JJ. Anti-HBV active constituents from Piper longum. Bioorg Med Chem Lett. 2013;23(7):2123-7. 
42. Mair CE, Liu R, Atanasov AG, Schmidtke M, Dirsch VM, Rollinger JM. Antiviral and anti-proliferative in vitro activities of piperamides from black pepper. Planta Med. 2016;82(S01):S1-381.

43. MehmoodY, Farooq U, Yousaf H, Riaz H, Mahmood RK, Nawaz A, et al. Antiviral activity of green silver nanoparticles produced using aqueous buds extract of Syzygium aromaticum. Pak J Pharm Sci. 2020;33(2(Supplementary)):839-45. PMID: 32863260.

44. Aboubakr HA, Nauertz A, Luong NT, Agrawal S, El-Sohaimy SA, Youssef MM, et al. In vitro Antiviral Activity of Clove and Ginger Aqueous Extracts against Feline Calicivirus, a Surrogate for Human Norovirus. J Food Prot. 2016;79(6):1001-12.

45. Sharma V, Thakur M, Chauhan NS, Dixit VK. Immunomodulatory activity of petroleum ether extract of Anacyclus pyrethrum. Pharm Biol. 2010;48(11):124754.

46. Javed T, Ashfaq UA, Riaz S, Rehman S, Riazuddin S. In-vitro antiviral activity of Solanum nigrum against Hepatitis C Virus. Virol J. 2011;8(1):26.

47. Kesharwani A, Polachira SK, Nair R, Agarwal A, Mishra NN, Gupta SK. AntiHSV-2 activity of Terminalia chebula Retz extract and its constituents, chebulagic and chebulinic acids. BMC Complement Altern Med. 2017;17(1):110.

48. Lin LT, Chen TY, Lin SC, Chung CY, Lin TC, Wang GH, et al. Broad-spectrum antiviral activity of chebulagic acid and punicalagin against viruses that use glycosaminoglycans for entry. BMC Microbiol. 2013;13(1):187.

49. Li P, Du R, Wang Y, Hou X, Wang L, Zhao X, et al. Identification of Chebulinic Acid and Chebulagic Acid as Novel Influenza Viral Neuraminidase Inhibitors. Front Microbiol. 2020;11:182.
50. Ansari S, Siddiqui MA, Malhotra S, Maaz M. Antiviral efficacy of qust (Saussurea lappa) and afsanteen (Artemisia absinthium) for chronic Hepatitis B A prospective single-arm pilot clinical trial. Phcog Res. 2018;10(3):282-90

51. Churiyah P, Olivia R, Elrade TT. Antiviral and Immunostimulant Activities of Andrographis paniculata. HAYATI Journal of Biosciences. 2015;22. 10.4308/ hjb.22.2.67.

52. Wintachai $P$, Kaur P, Lee RC, Ramphan S, Kuadkitkan A, Wikan N, et al. Activity of andrographolide against chikungunya virus infection. Sci Rep. 2015;5(1):14179.

53. Ramalingam S, Karupannan S, Padmanaban P, Vijayan S, Sheriff K, Palani G, et al. Anti-dengue activity of Andrographis paniculata extracts and quantification of dengue viral inhibition by SYBR green reverse transcription polymerase chain reaction. Ayu. 2018;39(2):87-91.

54. Sood R, Raut R, Tyagi P, Pareek PK, Barman TK, Singhal S, et al. Cissampelos pareira Linn: Natural Source of Potent Antiviral Activity against All Four Dengue Virus Serotypes. PLoS Negl Trop Dis. 2015;9(12):e0004255.

55. Parvez MK, Al-Dosari MS, Arbab AH, Niyazi $\mathrm{S}$. The in vitro and in vivo antihepatotoxic, anti-hepatitis B virus and hepatic CYP450 modulating potential of Cyperus rotundus. Saudi Pharm J. 2019;27(4):558-64.

56. https://conductscience.com/high-performance-liquid-chromatography-hplcprotocol/

57. https://v-kit.com/products/qualification-kits/lcms-kits

58. https://www.skz.de/en/research/technicalfacilities/pruefverfahren 1/ spektroskopie1/4870.Gas-Chromatography-coupled-with-Mass-SpectrometryGCMS.htm

Article History: Submission Date : 11-01-2021; Revised Date : 25-01-2021; Acceptance Date : 14-02-2021

Cite this article: Sivagami B, Sailaja B. A Review on Analytical Methods for Antiviral Phytoconstituents. J Young Pharm. 2021;13(1):7-13. 